\title{
Modyfication of the Rigid Polyurethane-Polyisocyanurate Foams
}

\author{
Bogusław Czupryński, Joanna Liszkowska, and Joanna Paciorek-Sadowska
}

Uniwersytet Kazimierza Wielkiego, Chodkiewicza 30, 85-064 Bydgoszcz, Poland

Correspondence should be addressed to Joanna Paciorek-Sadowska; sadowska@ukw.edu.pl

Received 15 May 2013; Accepted 22 October 2013; Published 29 January 2014

Academic Editor: Cengiz Soykan

Copyright (C) 2014 Bogusław Czupryński et al. This is an open access article distributed under the Creative Commons Attribution License, which permits unrestricted use, distribution, and reproduction in any medium, provided the original work is properly cited.

\begin{abstract}
The effect of polyethylene glycol 1500 on physicomechanical properties of rigid polyurethane-polyisocyanurate (PUR-PIR) foams has been studied. It was found that application of polyethylene glycol 1500 for synthesis of foams in amount from $0 \%$ to $20 \% w / w$ had an effect on reduction of brittleness and softening point, while the greater the increase in compressive strength the higher its content in foam composition was. Wastes from production of these foams were ground and subjected to glycolysis in diethylene glycol with the addition of ethanolamine and zinc stearate. Liquid brown products were obtained. Properties of the resulting products were defined in order to determine their suitability for synthesis of new foams. It was found that glycolysate 6 was the most suitable for reuse and its application in different amounts allowed us to prepare 4 new foams (nos. 25, 26, 27, and 28). Properties of foams prepared in this manner were determined and, on their basis, the suitability of glycolysates for production of rigid PUR-PIR foams was evaluated.
\end{abstract}

\section{Introduction}

The rigid polyurethane foams are polyadditive plastics characterized by the lowest thermal conductivity among all the materials applied as the heat insulators [1-3]. Their very good insulating properties are not fully used due to their high price. Therefore, the most often applied material for insulating the buildings and other objects is foamed polystyrene. The polyurethane foam of $5 \mathrm{~cm}$ in thickness gives the same insulating effect as the foamed polystyrene of about $10 \mathrm{~cm}$. Reduction of foam price is possible by applying such fillers in foam composition, which do not cause deterioration of the foam functional properties. The fillers applied to prepare rigid polyurethane foams should fulfill many requirements. They should be easily dispersed in polyol premixes and should not worsen conditions of processing. A good filler should be characterized by as low sedimentation in suspension as it is possible and even in the case when some sediment is formed, it should be easily mixed. The fillers should not absorb the components of composition, especially catalysts, since the decrease in their concentration can result in disturbances in polyaddition process [4].
When the costs of PUR-PIR foam production will be reduced, these foams will become competitive to other materials applied for insulating, for example, foamed polystyrene, mineral wool, and others.

During manufacturing (foaming) and moulding of rigid polyurethane foams, the waste products are produced. Waste products usually consist of defective casts, leakage from the mould, and residues from cleaning of devices and moulds. Other groups are waste materials such as, for example, packages. Part of polyurethane foam waste can come from recycling of cars. Used wrappings of heat pipelines (heat insulations and postconsumer waste) and others are also a source of rigid polyurethane foam wastes. Method of waste combustion is noneconomical. Reduced-in-size foam wastes are also applied as fillers to produce new foams (mechanical recycling). These fillers have often unfavourable effect on physicomechanical properties of the foams obtained. For the obvious reasons, methods based on waste decomposition by the use of chemical reagents to obtain liquid products become more and more popular [5-11]. The new products can be successfully used to produce polyurethane plastics. In the early 1970s of last century in Poland, this method of recycling (utilization) was investigated by research team of 
Department of Organic Technology in University of Technology and Agriculture in Bydgoszcz under the direction of Associate Professor Kozłowski and others [12]. The method of utilization consists in decomposition of waste polyurethane (PUR) and polyurethane-polyisocyanurate (PUR-PIR) foams in ethylene glycol in presence of catalysts at temperature from $150^{\circ} \mathrm{C}$ to $250^{\circ} \mathrm{C}$ for 2 to 10 hours.

Application of polyurethane foams as insulating materials is significantly limited by their thermal and heat resistance [13-18].

Heat resistance is connected with the physical changes occurring in insulation or foam product under the influence of temperature and the forces imposed. It is defined by the softening point and the method of determination. The molecular weight of plastic remains unchanged during these changes.

Thermal resistance is relevant to the breakdown temperature of the weakest bonds in foams and it is accompanied by the degradation of polymer. Molecular weight of foam is reduced. The softening point of the polyurethane foams is by tens degrees lower than the temperature of their decomposition.

Thermal resistance of foams is connected mainly with temperature of the thermal dissociation of bonds occurring in foams. The basic bond is urethane bond, which is more often formed in reaction between aromatic polyisocyanate and aliphatic polyol. Its temperature of thermal dissociation is about $200^{\circ} \mathrm{C}$. Ester and ether bonds (characterized by temperature of dissociation of about $260^{\circ} \mathrm{C}$ and $350^{\circ} \mathrm{C}$, resp.) are introduced into polymer chain with polyol. Polyols are oligomerols formed by polyoxyalkylation of the low molecular weight compounds. Polyoxypropylene fragments occurring in polyurethanes decompose at temperature within the range from $210^{\circ} \mathrm{C}$ to $230^{\circ} \mathrm{C}$. Besides polyurethane bonds, small amounts of allophanate bonds appear and their temperature of dissociation is $106^{\circ} \mathrm{C}$.

Water applied in order to obtain $\mathrm{CO}_{2}$ (porophor) reacts with polyisocyanate which results in formation of urea and biuret bonds whose temperatures of dissociation are $250^{\circ} \mathrm{C}$ and from $130^{\circ} \mathrm{C}$ to $145^{\circ} \mathrm{C}$, respectively [3].

Isocyanurate and carbodiimide bonds (temperatures of dissociation about $300^{\circ} \mathrm{C}$ and $240^{\circ} \mathrm{C}$, resp.) were introduced into the chain of the macromolecular compound as a result of polyisocyanate excess in relation to polyol (Table 1).

The aims of studies were as follows: (1) the determination of the effect of polyethylene glycol 1500 additive on physicomechanical properties and thermal resistance of block rigid polyurethane-polyisocyanurate foams, (2) performance of foam chemical recycling by alcoholysis combined with aminolysis, (3) preparation of the new materials by applying liquid products of decomposition of the previously synthesized PUR-PIR foams (initial foams), and (4) comparison of physicomechanical and thermal properties of the initial foams and the new foams prepared with addition of products of their decomposition (recyclates).

\section{Experimental}

2.1. Materials. The polyether with trade name Rokopol RF55 (product of oxypropylation of sorbitol $L_{\mathrm{OH}}=495 \mathrm{mg}$
TABLE 1: Temperatures of cleavage of chemical bonds occurring in PUR-PIR foams.

\begin{tabular}{lcc}
\hline No. & Bond & $\begin{array}{c}\text { Temperature of } \\
\text { cleavage }\left({ }^{\circ} \mathrm{C}\right)\end{array}$ \\
\hline 1 & Urethane & 200.0 \\
2 & Ester & 260.0 \\
3 & Ether & 350.0 \\
4 & Allophanate & 106.0 \\
5 & Urea & 250.0 \\
6 & Biuret & 140.0 \\
7 & Carbodiimide & 240.0 \\
8 & Isocyanurate & 300.0 \\
\hline
\end{tabular}

$\mathrm{KOH} / \mathrm{g}$, produced by NZPO “Rokita," Brzeg Dolny, Poland) and Casmonate 200 PMDI (technical polyisocyanate whose main component is diphenylmetane $4,4^{\prime}$-diisocyanate, made in Japan) were used to prepare the rigid PUR-PIR foams. Density of Cosmonate 200PMDI at temperature of $25^{\circ} \mathrm{C}$ was $1.04 \mathrm{~g} / \mathrm{cm}^{3}$ and its viscosity was approximately $1300 \mathrm{mPas}$. Content of NCO groups was $31 \%$. Polyether, products of foam glycolysis (recyclates) and polyisocyanate were characterized according to the following standards: ASTM D 2849-69 and ASTM D 1638-70.

Anhydrous potassium acetate in the form of $33 \%$ solution in diethylene glycol (Catalyst-12, POCh Gliwice, Poland) and DABCO (triethylenediamine produced by Hülls, Germany) in the form of $33 \%$ solution in dipropylene glycol were applied as catalysts in the foam composition. The polysiloxypolyalkyleneoxydimethylene surface-active agent Silicone L6900 (Witco Corp., Sweden) was used as a stabilizer of the foam structure. Foams were obtained in the presence of polyethylene glycol 1500 (white solid, dissolved in water, KOCH_LIGHT LABORATORIES LTD, Colnbrook, Buks, England). This glycol is a mixture of polymers with general formula $\mathrm{H}-\left(\mathrm{OCH}_{2}-\mathrm{CH}\right)_{n}-\mathrm{OH}$ corresponding to mean relative molecular weight of about 1500 .

2.1.1. Determination of Recipes for Rigid PUR-PIR Foams Preparation. The basis for the determination of recipes for preparation of the rigid PUR-PIR foams was the values of hydroxyl number of Rokpol RF-55 and products of glycolysis. They were developed taking into account also the percentage of isocyanate groups in PMDI applied. The basic raw materials (isocyanate and polyol) and products of glycolysis are chemically impure compounds. Therefore, recipes for synthesis of rigid foams were prepared taking advantage of gram-equivalents calculated by the following formulas:

$$
R_{\mathrm{OH}}=\frac{56100}{L_{\mathrm{OH}}},
$$

where $R_{\mathrm{OH}}$ is hydroxyl gram-equivalent and $L_{\mathrm{OH}}$ is hydroxyl number (determined by titration):

$$
R_{\mathrm{NCO}}=\frac{4200}{\% \mathrm{NCO}},
$$


TABLE 2: Receipts used to prepare rigid PUR-PIR foams with addition of polyethylene glycol 1500 (initial foams).

\begin{tabular}{|c|c|c|c|c|c|c|c|c|c|}
\hline \multirow{2}{*}{ Raw material, g } & \multicolumn{9}{|c|}{ Number of foam } \\
\hline & 0 & 1 & 2 & 3 & 4 & 5 & 6 & 7 & 8 \\
\hline Rokpol RF-55 & 60.0 & 60.0 & 60.0 & 60.0 & 60.0 & 60.0 & 60.0 & 60.0 & 60.0 \\
\hline Polyethylene glycol 1500 & 00.0 & 8.6 & 17.2 & 25.8 & 34.4 & 43.0 & 51.6 & 60.2 & 68.8 \\
\hline Silicone L 6900 & 4.6 & 4.6 & 4.6 & 4.6 & 4.6 & 4.6 & 4.6 & 4.6 & 4.6 \\
\hline DABCO & 2.8 & 2.8 & 2.8 & 2.8 & 2.8 & 2.8 & 2.8 & 2.8 & 2.8 \\
\hline Catalyst 12 & 6.5 & 6.5 & 6.5 & 6.5 & 6.5 & 6.5 & 6.5 & 6.5 & 6.5 \\
\hline Antiblaze TMCP & 34.6 & 34.6 & 34.6 & 34.6 & 34.6 & 34.6 & 34.6 & 34.6 & 34.6 \\
\hline Water & 3.15 & 3.15 & 3.15 & 3.15 & 3.15 & 3.15 & 3.15 & 3.15 & 3.15 \\
\hline Ongromat $30-20$ & 265.7 & 284.0 & 284.0 & 284.0 & 284.0 & 284.0 & 284.0 & 284.0 & 284.0 \\
\hline
\end{tabular}

${ }^{*} 2.5 \%(8.6 \mathrm{~g}), 5.0 \%(17.2 \mathrm{~g}), 7.5 \%(25.8 .0 \mathrm{~g}), 10.0 \%(34.4 \mathrm{~g}), 12.5 \%$ (43.0 g), $15.0 \%(51.6 \mathrm{~g}), 17.5 \%(60.2 \mathrm{~g})$, and $20.0 \%(68.8 \mathrm{~g})$ w/w of polyethylene glycol were added with respect to the sum of Rokpolu RF-55 and Cosmonate 200 PMDI weight.

TABLE 3: Basic utility properties of rigid PUR-PIR foams (numbers of foams as in Table 1)

\begin{tabular}{lcccccccc}
\hline $\begin{array}{l}\text { No. of } \\
\text { foam }\end{array}$ & $\begin{array}{c}\text { Apparent } \\
\text { density } \mathrm{kg} / \mathrm{m}^{3}\end{array}$ & $\begin{array}{c}\text { Compressive } \\
\text { strength } \mathrm{kPa}\end{array}$ & $\begin{array}{c}\text { Brittleness } \\
\%\end{array}$ & $\begin{array}{c}\text { Softening } \\
\text { point }{ }^{\circ} \mathrm{C}\end{array}$ & $\begin{array}{c}\text { Oxygen } \\
\text { index } \%\end{array}$ & $\begin{array}{c}\text { Retention } \\
\%\end{array}$ & $\begin{array}{c}\text { Loss of } \\
\text { volume \% }\end{array}$ & $\begin{array}{c}\text { Loss of } \\
\text { mass } \%\end{array}$ \\
\hline 0 & 36.9 & 221.7 & 41.1 & 230.0 & 22.1 & 76.6 & 0.00 & 0.00 \\
1 & 29.4 & 229.3 & 38.3 & 226.6 & 22.5 & 77.7 & -0.5 & 0.2 \\
2 & 29.2 & 236.2 & 36.6 & 223.6 & 22.4 & 79.9 & -0.8 & 0.5 \\
3 & 29.6 & 239.3 & 30.1 & 221.9 & 22.2 & 82.7 & -1.2 & 0.5 \\
4 & 29.8 & 242.1 & 28.7 & 219.7 & 21.8 & 84.4 & -1.0 & 0.4 \\
5 & 29.7 & 247.7 & 25.3 & 212.1 & 21.5 & 85.9 & -1.1 & 0.6 \\
6 & 29.7 & 250.1 & 22.4 & 209.4 & 22.5 & 87.2 & -0.9 & 0.4 \\
7 & 29.6 & 257.2 & 22.0 & 206.1 & 23.2 & 88.3 & -0.9 & 0.5 \\
8 & 29.5 & 265.9 & 21.7 & 205.9 & 23.4 & 88.8 & -0.8 & 0.5 \\
\hline
\end{tabular}

where $R_{\mathrm{NCO}}$ is isocyanate gram-equivalent and \% NCO is percentage of isocyanate groups (determined by titration).

Amount of isocyanate was calculated taking into account constant initial ratio of $\mathrm{NCO}: \mathrm{OH}$ groups equal to $3: 1$. The calculated amount was increased by the weight of isocyanate indispensable for reaction with water resulting in liberation of porophor-gaseous $\mathrm{CO}_{2}$.

Then, the contents of auxiliaries, which generally do not contain hydroxyl and isocyanate groups, were determined. Content of catalysts, flame retardants, and surfactants were expressed in $\% w / w$ per $100 \% w / w$ of the total amount of polyols and polyisocyanate. The calculated amounts of all the above mentioned components were mixed together and they constituted polyol premix, which then was mixed with isocyanate to obtain foams.

2.2. Method of Preparation of Rigid PUR-PIR Foams. The foams were prepared in laboratory scale by one-stage method, according to Table 2 (with polyethylene glycol 1500) and Table 5 (with products of glycolysis), from two-component system at the equivalent proportion of $\mathrm{NCO}$ to $\mathrm{OH}$ groups equal to $3: 1$. Component $A$ was obtained by precise mixing (speed of stirrer-1800 rpm and time-15 sec) of the respective amounts of Rokpol RF-55, catalysts, flame retardant, surface-active agent polyethylene glycol 1500, and recyclates. Component B was Cosmonate 200 PMDI. Both components ( $A$ and $B$ ) were mixed $(1800 \mathrm{rpm}, 10 \mathrm{sec})$ at respective weight ratios and poured into a metal rectangular tray where they were foamed in time dependent manner on the composition. An open mould was applied in our studies in order to enable the so-called free expansion of foam. The open mould was made from steel (thickness of $3 \mathrm{~mm}$ and internal dimensions $25 \times 25 \times 25 \mathrm{~cm}$ ). Five foaming operations were conducted for each system. During synthesis, the course of foaming of the reaction mixture was monitored by measuring the respective technological times (always measured from the moment when all components were mixed), that is, start time (reaching the so-called "creamy state," that is, beginning of foam expansion), time of expansion (to the moment when the foam attained maximum volume), and total time of gelation (to the moment when free surface of foam ceased to stick to a clean glass rod). The expanded foams were removed from the mould and thermostated for 4 hours at temperature of $120^{\circ} \mathrm{C}$. Then, foams were cut to samples according to the obligatory standards and their physicomechanical properties were determined. Band-saw was applied for cutting.

2.3. Determination of the Foam Properties. Physicomechanical properties of the obtained PUR-PIR foams were determined according to standards accepted for rigid polyurethane foams.

2.3.1. Determination of Apparent Density. Apparent density was determined according to ISO 845-1988 standard; tests 
TABle 4: Properties of the liquid products of the initial foam decomposition.

\begin{tabular}{lcccc}
\hline No. of foam & $\begin{array}{c}\text { Content of polyethylene } \\
\text { glycol } 1500[\%]\end{array}$ & $\begin{array}{c}\text { Density (temp. } \\
\left.\text { of } 25^{\circ} \mathrm{C}\right)\left[\mathrm{kg} / \mathrm{m}^{3}\right]\end{array}$ & $\begin{array}{c}\text { Viscosity (temp. } \\
\left.\text { of } 25^{\circ} \mathrm{C}\right)[\mathrm{mPa} \cdot \mathrm{s}]\end{array}$ & $\begin{array}{c}\text { Hydroxyl number } \\
{[\mathrm{mg} \mathrm{KOH} / \mathrm{g}]}\end{array}$ \\
\hline 0 & 0.0 & 1100.0 & 2410.0 & 2425.0 \\
1 & 2.5 & 1130.0 & 1965.0 & 420.0 \\
2 & 5.0 & 1150.0 & 1981.0 & 433.0 \\
3 & 7.5 & 1170.0 & 3325.0 & 44.0 \\
4 & 10.0 & 1110.0 & 3337.0 & 450.0 \\
5 & 12.5 & 1126.0 & 3977.0 & 467.0 \\
6 & 15.0 & 1095.0 & 4011.0 & 477.0 \\
8 & 17.5 & 1134.0 & 4237.0 & 481.0 \\
\hline
\end{tabular}

were carried out for 3 samples of each foam in the form of rectangular cubes (volume of $125 \mathrm{~cm}^{3}$ ). Samples of foams were measured by a slide caliper with an accuracy of $0.1 \mathrm{~mm}$ and were weighted accurately to $0.0001 \mathrm{~g}$. Arithmetic mean from densities calculated as the mass to volume ratio was accepted as the result.

2.3.2. Determination of Compressive Strength at Sample Deformation of $10 \%$. Compressive strength was determined according to ISO standard 844:1993. Tests were carried out on 5 foam samples (dimensions $50 \times 50 \times 50 \mathrm{~mm}$ ). The maximum load causing reduction in height of foam sample by $10 \%$ with respect to the initial one in direction of foam expansion was determined. The compressive strength at deformation by $10 \%$ was calculated as a ratio of load causing deformation by $10 \%$ to the initial surface of sample cross-section. The mean value from 5 measurements was accepted as the result.

2.3.3. Determination of Brittleness. The determinations were carried our according to ASTM C-421-61 standard in a cubical box $(190 \times 197 \times 197 \mathrm{~mm})$ made from an oaken wood and rotating about the axis with a speed of $60 \pm 2 \mathrm{rpm}$. The box was filled with 24 oak cubes of side $20 \mathrm{~mm}$. Brittleness was calculated as a loss in mass (in percent) of 12 foam cubes (side of $25 \mathrm{~mm}$ ) during drum rotation for 10 minutes in relation to their initial mass. Consider

$$
K=\frac{m_{1}-m_{2}}{m_{1}} 100 \%,
$$

where $K$ is brittleness in $\%, m_{1}$ is sample mass before test, and $m_{2}$ is sample mass after test.

Determination of the foam flammability was done according to simplified chimney test (ASTM D 1692-59T).

Three samples of foams with dimensions of $150 \times 20 \times$ $20 \mathrm{~mm}$ were subjected to test. Combustion was performed in a vertical column (chimney) of $300 \times 57 \times 54 \mathrm{~mm}$ by a flame from gas burner supplied with propane-butane. The weighted sample was brought into contact with burner flame for 10 seconds and then, the burner was removed and time of the sample free burning was measured by stopwatch. After combustion, the samples were weighted once again. The results were time of free burning and retention in chimney test. Residue of mass (retention) after combustion (in \%) was calculated from the formula:

$$
R=m_{2} m_{1}^{-1} \times 100 \%,
$$

where $R$ is retention (residue after combustion) in $\%, m_{1}$ is mass of sample before burning [g], and $m_{2}$ is mass of sample after burning $[\mathrm{g}]$.

\subsubsection{Determination of Flammability according to Horizontal}

Test. Tests were performed for 3 foam samples of dimensions $150 \times 50 \times 13 \mathrm{~mm}$ according to ASTM D-1692-74 standard. The tested samples in horizontal position with marked line at a distance of $125 \mathrm{~mm}$ were burned by the flame from propane-butane burner for 60 seconds. Then, the burner was removed and time of the sample free burning was measured by stopwatch. The range of flame propagation in $\mathrm{mm}$ and time of free burning in horizontal test were accepted as results.

\subsubsection{Determination of Changes in Linear Dimensions and} Volume (ISO 1923:1981). The determinations were performed for 3 samples (dimensions $50 \times 50 \times 50$ ) of each foam with indicated direction of growth. Changes in the linear dimensions and volume were determined after 48 hours of sample thermostating at temperature of $120^{\circ} \mathrm{C}$. Change in linear dimensions was determined in accordance with direction of the foam growth and it was calculated in $\%$ from equation

$$
\Delta l=\frac{l-l_{0}}{l_{0}} \times 100,
$$

where $l_{0}$ is length of sample before thermostating and $l$ is length of sample after thermostating.

However, change in volume (in \%) was calculated according to formula:

$$
\Delta V=\frac{V-V_{0}}{V_{0}} \times 100,
$$

where $V_{0}$ is volume of sample before thermostating and $V$ is volume of sample after thermostating.

Dimensions were measured by a slide caliper with accuracy to $0.1 \mathrm{~mm}$. Samples were thermostated in a drier with circulation of air. 
TABLE 5: Receipts of foams containing recyclates of standard foam (foams 1-4) and polyethylene glycol 1500 (foams 5-36).

\begin{tabular}{|c|c|c|c|c|c|c|c|c|c|c|c|}
\hline \multirow{3}{*}{$\begin{array}{l}\text { No. of foam as in } \\
\text { Table } 1\end{array}$} & \multirow{3}{*}{$\begin{array}{l}\text { No. of foam obtained } \\
\text { from recyclates } \\
0.0\end{array}$} & \multirow{3}{*}{$\begin{array}{c}\text { Rokpol RF-55 (g) } \\
56.7\end{array}$} & \multicolumn{9}{|c|}{ Products of foam decomposition (g) } \\
\hline & & & 0 & 1 & 2 & 3 & 4 & 5 & 6 & 7 & 8 \\
\hline & & & 0.0 & & & & & & & & \\
\hline \multirow{4}{*}{0} & 1 & 51.0 & 6.7 & & & & & & & & \\
\hline & 2 & 45.3 & 13.4 & & & & & & & & \\
\hline & 3 & 39.6 & 20.0 & & & & & & & & \\
\hline & 4 & 34.0 & 26.7 & & & & & & & & \\
\hline \multirow{4}{*}{1} & 5 & 51.0 & & 6.5 & & & & & & & \\
\hline & 6 & 45.3 & & 13.0 & & & & & & & \\
\hline & 7 & 39.6 & & 19.4 & & & & & & & \\
\hline & 8 & 34.0 & & 25.9 & & & & & & & \\
\hline \multirow{4}{*}{2} & 9 & 51.0 & & & 6.4 & & & & & & \\
\hline & 10 & 45.3 & & & 12.8 & & & & & & \\
\hline & 11 & 39.6 & & & 19.3 & & & & & & \\
\hline & 12 & 34.0 & & & 25.7 & & & & & & \\
\hline \multirow{4}{*}{3} & 13 & 51.0 & & & & 6.3 & & & & & \\
\hline & 14 & 45.3 & & & & 12.6 & & & & & \\
\hline & 15 & 39.6 & & & & 19.0 & & & & & \\
\hline & 16 & 34.0 & & & & 25.3 & & & & & \\
\hline \multirow{4}{*}{4} & 17 & 51.0 & & & & & 6.2 & & & & \\
\hline & 18 & 45.3 & & & & & 12.5 & & & & \\
\hline & 19 & 39.6 & & & & & 18.7 & & & & \\
\hline & 20 & 34.0 & & & & & 25.0 & & & & \\
\hline \multirow{4}{*}{5} & 21 & 51.0 & & & & & & 6.1 & & & \\
\hline & 22 & 45.3 & & & & & & 12.3 & & & \\
\hline & 23 & 39.6 & & & & & & 18.4 & & & \\
\hline & 24 & 34.0 & & & & & & 25.5 & & & \\
\hline \multirow{4}{*}{6} & 25 & 51.0 & & & & & & & 6.1 & & \\
\hline & 26 & 45.3 & & & & & & & 12.2 & & \\
\hline & 27 & 39.6 & & & & & & & 18.2 & & \\
\hline & 28 & 34.0 & & & & & & & 24.3 & & \\
\hline \multirow{4}{*}{7} & 29 & 51.0 & & & & & & & & 5.9 & \\
\hline & 30 & 45.3 & & & & & & & & 11.8 & \\
\hline & 31 & 39.6 & & & & & & & & 17.6 & \\
\hline & 32 & 34.0 & & & & & & & & 23.5 & \\
\hline \multirow{4}{*}{8} & 33 & 51.0 & & & & & & & & & 5.8 \\
\hline & 34 & 45.3 & & & & & & & & & 11.7 \\
\hline & 35 & 39.6 & & & & & & & & & 17.5 \\
\hline & 36 & 34.0 & & & & & & & & & 23.3 \\
\hline
\end{tabular}

2.3.6. Determination of Loss in Mass (PN-ISO 4590:1994). The loss in mass was determined for 3 samples $(50 \times 50 \times$ $50 \mathrm{~mm}$ ) after 48 hours of thermostating at temperature of $120^{\circ} \mathrm{C}$ in drier with circulation of air. Samples were weighted before and after thermostating. Loss in mass was calculated in percent from the formula:

$$
\Delta m=\frac{m_{0}-m}{m_{0}}
$$

where $m_{0}$ is mass of sample before thermostating and $m$ is mass of sample after thermostating.

2.3.7. Determination of Softening Point. Softening point was determined as a thermal resistance under compressive stress according to DIN 53424 standard. Samples of foam $(20 \times$ $20 \times 20 \mathrm{~mm}$ ) were subjected to the action of compressive load of $0.25 \mathrm{kG} / \mathrm{cm}^{2}$ longwise a direction of the foam expansion. 
TABLE 6: Basic utility properties of rigid PUR-PIR foams with addition of glycolysis products (nos. as in Table 4).

\begin{tabular}{|c|c|c|c|c|c|c|c|c|}
\hline $\begin{array}{l}\text { No. of } \\
\text { foam }\end{array}$ & $\begin{array}{c}\text { Apparent } \\
\text { density } \mathrm{kg} / \mathrm{m}^{3}\end{array}$ & $\begin{array}{l}\text { Compressive } \\
\text { strength } \mathrm{kPa}\end{array}$ & $\begin{array}{c}\text { Brittleness } \\
\% \\
\end{array}$ & $\begin{array}{l}\text { Softening } \\
\text { point }{ }^{\circ} \mathrm{C} \\
\end{array}$ & $\begin{array}{l}\text { Oxygen } \\
\text { index \% }\end{array}$ & $\begin{array}{c}\text { Retention } \\
\% \\
\end{array}$ & $\begin{array}{l}\text { Change of } \\
\text { volume \% }\end{array}$ & $\begin{array}{l}\text { Loss of } \\
\text { mass \% } \\
\end{array}$ \\
\hline 0 & 36.9 & 221.7 & 41.1 & 230.0 & 22.1 & 76.6 & 0.0 & 0.0 \\
\hline 1 & 35.5 & 222.1 & 40.3 & 229.8 & 22.1 & 76.6 & 0.0 & 0.0 \\
\hline 2 & 35.4 & 222.5 & 38.2 & 229.3 & 22.5 & 77.8 & 0.0 & 0.0 \\
\hline 3 & 35.9 & 223.1 & 36.7 & 229.1 & 22.7 & 77.9 & 0.0 & 0.0 \\
\hline 4 & 35.4 & 223.3 & 34.9 & 228.9 & 22.9 & 78.1 & 0.0 & 0.0 \\
\hline 5 & 36.3 & 224.7 & 38.2 & 227.3 & 22.4 & 77.9 & 0.0 & 0.0 \\
\hline 6 & 37.0 & 227.3 & 37.3 & 227.1 & 22.6 & 78.7 & 0.0 & 0.0 \\
\hline 7 & 36.7 & 229.1 & 36.4 & 226.7 & 227 & 79.9 & 0.0 & 0.0 \\
\hline 8 & 36.8 & 230.0 & 36.0 & 226.1 & 22.9 & 80.0 & 0.0 & 0.3 \\
\hline 9 & 36.9 & 225.3 & 36.3 & 225.4 & 22.6 & 78.3 & 0.0 & 0.0 \\
\hline 10 & 37.1 & 227.1 & 35.1 & 224.9 & 22.8 & 79.5 & 0.0 & 0.0 \\
\hline 11 & 37.0 & 228.2 & 34.7 & 223.7 & 23.0 & 80.3 & 0.0 & 0.0 \\
\hline 12 & 36.9 & 228.9 & 34.1 & 223.3 & 23.0 & 81.3 & 0.0 & 0.0 \\
\hline 13 & 37.5 & 226.3 & 33.7 & 223.5 & 22.8 & 79.4 & 0.0 & 0.0 \\
\hline 14 & 37.7 & 227.7 & 32.5 & 221.1 & 23.0 & 80.2 & 0.0 & 0.0 \\
\hline 15 & 37.8 & 228.5 & 31.3 & 219.7 & 23.1 & 81.7 & 0.0 & 0.2 \\
\hline 16 & 37.9 & 229.3 & 30.1 & 218.9 & 23.1 & 81.6 & 0.0 & 0.0 \\
\hline 17 & 38.9 & 231.2 & 30.1 & 220.7 & 22.8 & 79.6 & 0.0 & 0.0 \\
\hline 18 & 36.6 & 236.3 & 28.3 & 218.6 & 23.0 & 80.9 & 0.0 & 0.3 \\
\hline 19 & 38.7 & 239.7 & 26.4 & 217.7 & 23.2 & 81.7 & 0.0 & 0.1 \\
\hline 20 & 38.8 & 240.2 & 23.0 & 216.4 & 23.5 & 82.9 & 0.0 & 0.0 \\
\hline 21 & 37.7 & 233.3 & 27.1 & 218.9 & 22.9 & 80.0 & -0.3 & 0.0 \\
\hline 22 & 37.8 & 235.7 & 25.9 & 217.1 & 23.1 & 81.4 & -0.5 & 0.3 \\
\hline 23 & 37.9 & 237.8 & 23.0 & 215.9 & 23.6 & 82.7 & -0.4 & 0.1 \\
\hline 24 & 38.3 & 241.4 & 22.1 & 214.1 & 23.9 & 83.6 & -0.6 & 0.1 \\
\hline 25 & 38.7 & 240.1 & 25.1 & 227.7 & 23.7 & 82.9 & 0.0 & 0.0 \\
\hline 26 & 38.9 & 244.7 & 23.4 & 227.1 & 23.9 & 83.9 & 0.0 & 0.0 \\
\hline 27 & 38.9 & 246.4 & 21.1 & 224.7 & 24.5 & 84.8 & 0.0 & 0.0 \\
\hline 28 & 39.4 & 249.9 & 18.4 & 224.1 & 25.1 & 86.4 & 0.0 & 0.0 \\
\hline 29 & 37.7 & 237.4 & 27.1 & 218.7 & 22.7 & 79.9 & 0.0 & 0.2 \\
\hline 30 & 37.9 & 238.9 & 25.4 & 216.5 & 22.9 & 80.3 & 0.7 & 0.6 \\
\hline 31 & 37.9 & 242.7 & 23.2 & 213.9 & 23.0 & 80.8 & 0.9 & 0.7 \\
\hline 32 & 38.1 & 243.8 & 20.7 & 211.9 & 23.9 & 81.7 & 0.3 & 0.7 \\
\hline 33 & 37.1 & 234.4 & 30.1 & 215.5 & 23.0 & 81.0 & 0.0 & 0.0 \\
\hline 34 & 37.3 & 236.1 & 28.4 & 213.7 & 23.6 & 82.6 & 0.0 & 0.0 \\
\hline 35 & 37.1 & 237.9 & 26.2 & 211.3 & 23.9 & 83.4 & 0.7 & 0.6 \\
\hline 36 & 37.7 & 238.6 & 23.3 & 209.7 & 24.7 & 84.7 & 0.9 & 1.1 \\
\hline
\end{tabular}

Temperature rise during the test was $50^{\circ}$ per hour. Temperature at which the sample was compressed by $2 \mathrm{~mm}$ was accepted as the softening point.

2.3.8. Determination of Thermal Resistance. The foams were grinded in Janetzky's ball mill and then, they were subjected to thermogravimetric analysis within the range of temperature from $20^{\circ} \mathrm{C}$ to $800^{\circ} \mathrm{C}$. Thermal resistance of foams was determined under dynamic conditions in air atmosphere at the heating rate of $5 \mathrm{deg} / \mathrm{min}$. Tests were carried out using derivatograph produced by MOM Budapest (Paulik-PaulikErdey).

2.3.9. IR Analysis. IR analysis of rigid PUR-PIR foams was conducted by $\mathrm{KBr}$ technique within the range from $4000 \mathrm{~cm}^{-1}$ to $400 \mathrm{~cm}^{-1}$ by the use of Victor spectrophotometer (Brucker). 
2.3.10. Content of Closed Cells. Content of the closed cells was determined in accordance to PN-ISO 4590:1994 standard by method II (dimensions of samples: $100 \times 30 \times 30 \mathrm{~mm}$ ). This method is used for determining the percentage of closed cells in rigid porous plastics. It consists in the determination of the relative pressure drop (earlier calibrated for the volume standards) from the differences in indications on the scale of manometer whose one arm was opened to atmosphere.

2.3.11. Heat Conductivity. Heat conductivity (value of the thermal conductance $\lambda$ ) of the foam samples (dimensions of $200 \times 200 \times 25 \mathrm{~mm}$ ) was determined by the use of apparatus FOX 200 (Lasercomp). It allowed us to determine $\lambda$ value within the range from 20 to $100 \mathrm{~mW} /(\mathrm{m} \cdot \mathrm{K})$. The method consists in determining the amount of heat flowing through a given material on opposite sides of sample in the time unit during steady heat flow at constant difference of temperature.

\subsubsection{Decomposition of Rigid PUR-PIR Foams and Charac-} teristics of Alcoholysis Products. Decomposition (glycolysis) of 9 types of rigid PUR-PIR foams (standard foam without filler), prepared from components presented in Table 2 (foams numbers 0-8), was performed in three-neck glass flask $\left(0.5 \mathrm{dm}^{3}\right)$ equipped with a stirrer, reflux, and thermometer. Diethylene glycol (160 g, product POCH, Gliwice), ethanoloamine ( $40 \mathrm{~g}$, product POCh, Gliwice), and catalyst - zinc stearate ( $3 \mathrm{~g}$, product POCH Gliwice) were introduced into a flask. Content of the flask was heated in electric bath to the mixture boiling point and then, $90.0 \mathrm{~g}$ (in portions of $15 \mathrm{~g}$ ) of the grinded foam samples was dosed (laboratory screw-disk and ball mills). Alcoholysis was carried out at different temperatures (in the range from $150^{\circ} \mathrm{C}$ to $250^{\circ} \mathrm{C}$ ). The reaction time ranged from 3.5 to $4.0 \mathrm{~h}$. After completion of foam dosing, the reaction mixture was heated for another 2 hours at temperature from $200^{\circ} \mathrm{C}$ to $215^{\circ} \mathrm{C}$ in order to obtain homogeneous solution. The quantitative composition of degradation products was monitored during decomposition process. The following parameters were determined for the obtained products: density (PN-92/C-04504), viscosity (PN86/C-89082.04), and hydroxyl number (PN-93/C-89052.03).

\section{Results and Discussion}

Rigid polyurethane-polyisocyanurate foams with polyethylene glycol 1500 were prepared by one-stage method in the proportion of isocyanate to hydroxyl groups $3: 1$. Blowing agent for the systems was carbon dioxide formed in reaction of PMDI with water. Addition of polyethylene glycol 1500 for synthesis of foams caused a slight extension of start, expansion, and gelation, times compared to standard foam, that is, from $14.1 \mathrm{~s}, 21.0 \mathrm{~s}$, and $38.5 \mathrm{~s}$ (standard foam) to $15.1 \mathrm{~s}$, $23.0 \mathrm{~s}$, and $41.7 \mathrm{~s}$ (foams with $20 \% \mathrm{w} / \mathrm{w}$ of glycol), respectively. Thus, addition of polyethylene glycol 1500 results in lower reactivity of the mixture: Rokpol RF 55 and polyethylene glycol 1500 in relation to PMDI then commonly used polyol. Polyethylene glycol can be treated as a typical chain extension. Probable course of the reaction between isocyanate, polyol, and polyethylene glycol can be summarized as follows:

$$
\begin{aligned}
& 2 \mathrm{R}-\mathrm{N}=\mathrm{C}=\mathrm{O}+\mathrm{R}^{\prime}-\mathrm{OH}+\left(\mathrm{OCH}_{2}-\mathrm{CH}\right)_{n}-\mathrm{OH} \\
& \text { polyisocyanate }{ }^{+}{ }_{\text {polyol }}+{ }_{\text {polyethylene glycol }} \\
& \rightarrow \underset{\text { polyurethane }}{\mathrm{RNH}-\mathrm{CO}-\mathrm{OR}^{\prime}}+\stackrel{-\left[\mathrm{R}-\mathrm{NH}-\mathrm{CO}-\mathrm{OR}^{\prime}-\mathrm{O}-\mathrm{CO}-\mathrm{NH}-\mathrm{R}-\mathrm{NH}-\mathrm{C}-\mathrm{O}-\left(\mathrm{OCH}_{2}-\mathrm{CH}\right)_{n}-\mathrm{O}-\right]_{m}-}{\text { polyurethane with build-in molecule of polyethylene glycol }}
\end{aligned}
$$

On the basis of IR spectrum, it was found that the prepared foams were characterized by the expected chemical structure of polyurethane-polyisocyanurate foams, since vibration spectra corresponding to both urethane bond (2180$\left.1710 \mathrm{~cm}^{-1}\right)$ and isocyanurate ring $\left(1710-1680\right.$ oraz $\left.1410 \mathrm{~cm}^{-1}\right)$ occurred in their spectra.

Properties of polyurethane-polyisocyanurate foams (standard and with polyethylene glycol) are presented in Table 3. Apparent densities of foams containing polyethylene glycol 1500 were lower than that of standard foam $(36.96 \mathrm{~kg} /$ $\mathrm{m}^{3}$ ). Apparent density of foams containing polyethylene glycol from $2.5 \%$ to $20.0 \% w / w$ was $29.5 \pm 3 \mathrm{~kg} / \mathrm{m}^{3}$. Polyethylene glycol probably behaves like a typical crosslinking compound facilitating formation of a more orderly structure of foams. Therefore, its presence in the foam causes a significant reduction in brittleness from $41.1 \%$ (standard foam without polyethylene glycol 1500 ) to $21.7 \%$ (foam no. 8).
The compressive strength increases as the content of polyethylene glycol 1500 is increased in foam composition. The limiting values are as follows: $221.7 \mathrm{kPa}$ (foam no. 0) and $265.9 \mathrm{kPa}$ (foam no. 8) and corresponding relationship is rectilinear.

Moreover, content of closed cells was determined in samples of foams. Their content increased in comparison with standard foam and was equal to $82.7 \%$ for standard foam, $83.6 \%$ for foam no. 1 , and $90.3 \%$ for foam no. 8 . Addition of polyethylene glycol 1500 causes decrease in water absorptivity. Absorptivity of water for standard foam was $6.3 \% v / v$ and it decreased to $3.7 \% v / v$ as the amount of polyethylene glycol was increased. It can be due to smaller share of closed cells in standard foam than in foams with addition of polyethylene glycol 1500.

Studies on loss of volume, loss of weight, and stability of linear dimensions after $48 \mathrm{~h}$ of thermostating at temperature of $120^{\circ} \mathrm{C}$ showed no effect of presence and content of 
polyethylene glycol on changes in above mentioned properties.

As the content of polyethylene glycol was increased in foam composition from $0 \%$ to $20 \% w / w$, flammability of foams slightly decreased resulting in a slight increase in oxygen index from $22.1 \%$ (foam number 0 ) to $23.4 \%$ (foam number 8 ) and retention from $76.6 \%$ (foam number 0 ) to $88.8 \%$ (foam number 8 ), respectively.

Thermal resistance of foams was characterized by thermogravimetric analysis in the previously described conditions. Example of thermogram of foam sample is presented in Figure 1. On the basis of TG (change of mass) and DTG (derivative of change of mass) curves, the characteristics were determined as follows [6-10]: temperature of the first loss of foam mass $\left(T_{1},{ }^{\circ} \mathrm{C}\right)$, extrapolated temperature of the beginning of the first loss of mass $\left(T_{2},{ }^{\circ} \mathrm{C}\right)$, temperature of the beginning of rapid decomposition of foam $\left(T_{3},{ }^{\circ} \mathrm{C}\right.$ determined according to ISO 7111 standard as an intersection of tangents), and temperature of the highest rate of loss of foam mass ( $T_{\max },{ }^{\circ} \mathrm{C}$, corresponding to extreme on DTG curve). Thermogram showing dependence between temperatures $T_{1}$, $T_{2}, T_{3}$, and $T_{4}$ and content of polyethylene glycol in foams is presented in Figure 2. As the content of glycol was increased from $0 \%$ to $20 \% w / w, T_{1}, T_{2}, T_{3}$, and $T_{4}$ increased from $85^{\circ} \mathrm{C}$ (foam 0 , standard) to $104^{\circ} \mathrm{C}$ (foam 8), from $210^{\circ} \mathrm{C}$ (foam 0 ) to $223^{\circ} \mathrm{C}$ (foam 8 ), from $240^{\circ} \mathrm{C}$ (foam 0 ) to $258^{\circ} \mathrm{C}$ (foam 8), and from $280^{\circ} \mathrm{C}$ (foam 0 ) to $299^{\circ} \mathrm{C}$ (foam 8), respectively. The cause of the first loss of mass is diffusion of carbon dioxide which acts as a blowing agent. It is formed in reaction of the excess of isocyanate groups with water. At temperature from $85^{\circ} \mathrm{C}$ to $104^{\circ} \mathrm{C}$, diffusion of triethylenediamine (DABCO) from foams can occur. DABCO in the form of $33 \%$ solution in dipropylene glycol is applied as a catalyst for synthesis of PUR. Decomposition of urea formed by reaction of polyisocyanate with water and urethane groups has an effect on $T_{3}$ values. As the content of polyethylene glycol increases in foam composition, increase in participation of flexible segments occurs, among others, which affects increase in resistance to higher temperature. It results in increase of $T_{4}$ by $19^{\circ} \mathrm{C}$.

Properties of the liquid products of decomposition of the initial foams [standard (foam 0 ) and with addition of $2.5 \%$ to $20 \% w / w$ (foams $0-8$ )] are presented in Table 4 . As a result of foam glycolysis coupled with aminolysis, homogeneous liquid products of high viscosity (from $1100,0 \mathrm{mPa} \cdot \mathrm{s}$ to $1170,0 \mathrm{mPa} \cdot \mathrm{s}$ ) and dark colour were obtained. Probably, they are a mixture of polyol applied for synthesis, urethane polyol, carbamates, and dicarbamates with terminal groups $\mathrm{OH}$ and $\mathrm{NH}_{2}$. Increased temperature causes that also diamines, amines, and carbon dioxide are formed during reaction. Then, diamines react with urethane groups forming urea (aminolysis). In reaction of urethane groups with ethanoloamine, polyols were obtained as follows: urethane and original and urea derivatives (reactions (9), (10)):

$$
\begin{aligned}
& \underset{\text { polyurethane }}{-[\mathrm{R}-\mathrm{NH}-\mathrm{CO}-\mathrm{O}]_{n}-\mathrm{R}^{\prime}}+\underset{\mathrm{HO}-\mathrm{CH}_{2}-\mathrm{CH}_{2}-\mathrm{O}-\mathrm{CH}_{2}-\mathrm{CH}_{2}-\mathrm{OH}}{\text { diethylene glycol }} \\
& \longrightarrow-\begin{array}{c}
-\left[\mathrm{R}-\mathrm{NH}-\mathrm{CO}-\mathrm{O}-\mathrm{O}-\mathrm{CH}_{2}-\mathrm{CH}_{2}-\mathrm{O}\right]_{n}-\mathrm{CH}_{2}-\mathrm{CH}_{2}-\mathrm{OH} \\
\text { polyester of aminocarboxyl acid }
\end{array}+\underset{\text { original polyol }}{\mathrm{R}^{\prime}-\mathrm{OH}} \begin{array}{c}
{[\mathrm{R}-\mathrm{NHCO}-\mathrm{O}]_{n}-\mathrm{R}^{\prime}} \\
\text { polyurethane }
\end{array} \\
& +\begin{array}{c}
\mathrm{NH}_{2}-\mathrm{CH}_{2}-\mathrm{CH}_{2}-\mathrm{OH} \\
\text { ethanoloamine }
\end{array} \longrightarrow \begin{array}{c}
-[\mathrm{R}-\mathrm{NH}-\mathrm{CO}-\mathrm{O}]_{n-1}-\mathrm{CH}_{2}-\mathrm{CH}_{2}-\mathrm{NH}_{2} \\
\text { carbomate polyol }
\end{array} \\
& +\underset{\text { original polyol }}{\mathrm{R}^{\prime}-\mathrm{OH}+}+\begin{array}{c}
\mathrm{R}-\mathrm{NH}-\mathrm{CO}-\mathrm{NH}-\mathrm{CH}_{2}-\mathrm{CH}_{2}-\mathrm{OH}+\mathrm{R}^{\prime}-\mathrm{NH}_{2} \\
\text { urea derivative }
\end{array}+\begin{array}{c}
\mathrm{R}-\mathrm{NH}_{2} \\
\text { amines }
\end{array}
\end{aligned}
$$

The determined hydroxyl number of these products of decomposition is from $420.0 \mathrm{mg} \mathrm{KOH} / \mathrm{g}$ to $481.0 \mathrm{mg} \mathrm{KOH} / \mathrm{g}$. The hydroxyl number was used to prepare recipes for the preparation of new rigid foams with their participation. The recipes of these foams are presented in Table 5 and their properties in Table 6 . In addition to polyol and recyclates (products of glycolysis of foams) presented in Table 5, other components were introduced into foam composition in the following amounts: Silicone L-6900-5.16 g; DABCO 33-LV $3.1 \mathrm{~g}$; catalyst $12-7.2 \mathrm{~g}$; Antiblaze- $51.6 \mathrm{~g}$, distilled water3.78 g; Casmonate 200 PMDI-286 g.

Addition of decomposition products (glycolysis) to foams in amount from 0.1 to 0.4 of chemical equivalent at simultaneous the same reduction of Rokpol 55 content in foams does not cause significant changes in parameters of processing and apparent density of the foams obtained. Start time of these foams was from $17 \mathrm{~s}$ to $23 \mathrm{~s}$, time of expansion and time of gelation did not exceed $57 \mathrm{~s}$, and apparent density was within the range from $35.4 \mathrm{~kg} / \mathrm{m}^{3}$ to $38.9 \mathrm{~kg} / \mathrm{m}^{3}$ (Table 6).

Increase of recyclate content in the new rigid foams from 0.1 to 0.4 of chemical equivalent causes the highest increase of compressive strength in case of addition of recyclate obtained as a result of glycolysis of foams with addition of $15 \% w / w$ of polyethylene glycol, that is, from $221.7 \mathrm{kPa}$ (foam 0) to $249.9 \mathrm{kPa}$ (foam 28, with addition of 0.4 of chemical equivalent of foam glycolysis product with $15 \%$ of polyethylene glycol 1500). It was found that product of decomposition obtained from foam without fillers had insignificant effect on this property (foams 0-4, Table 5).

In all cases, brittleness was reduced with the increase of the content of glycolysis products in foam composition. Foams with addition of 0.4 of chemical equivalent (foams 28) 


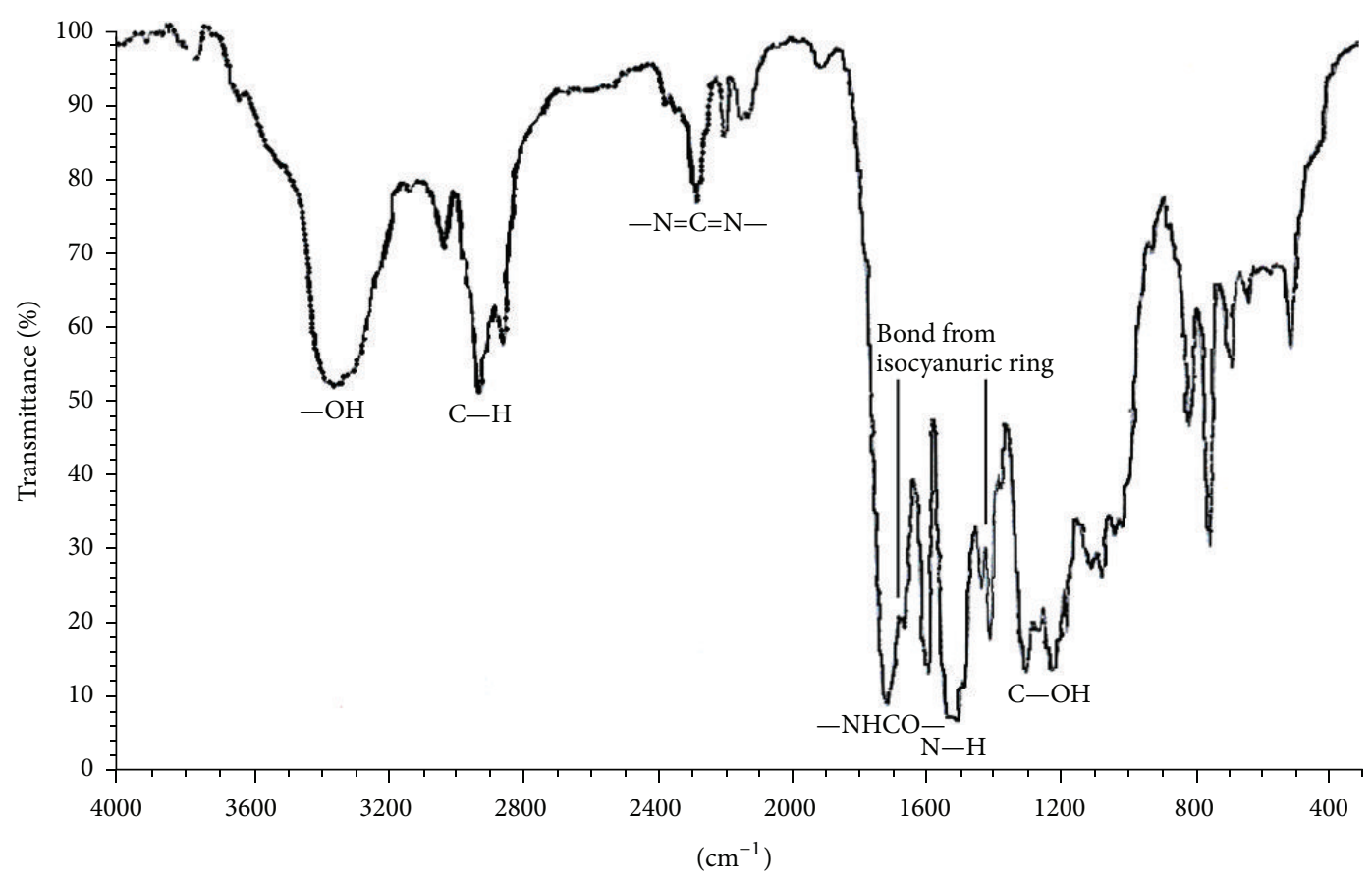

FIGURE 1: IR spectrum of standard PUR-PIR foam.

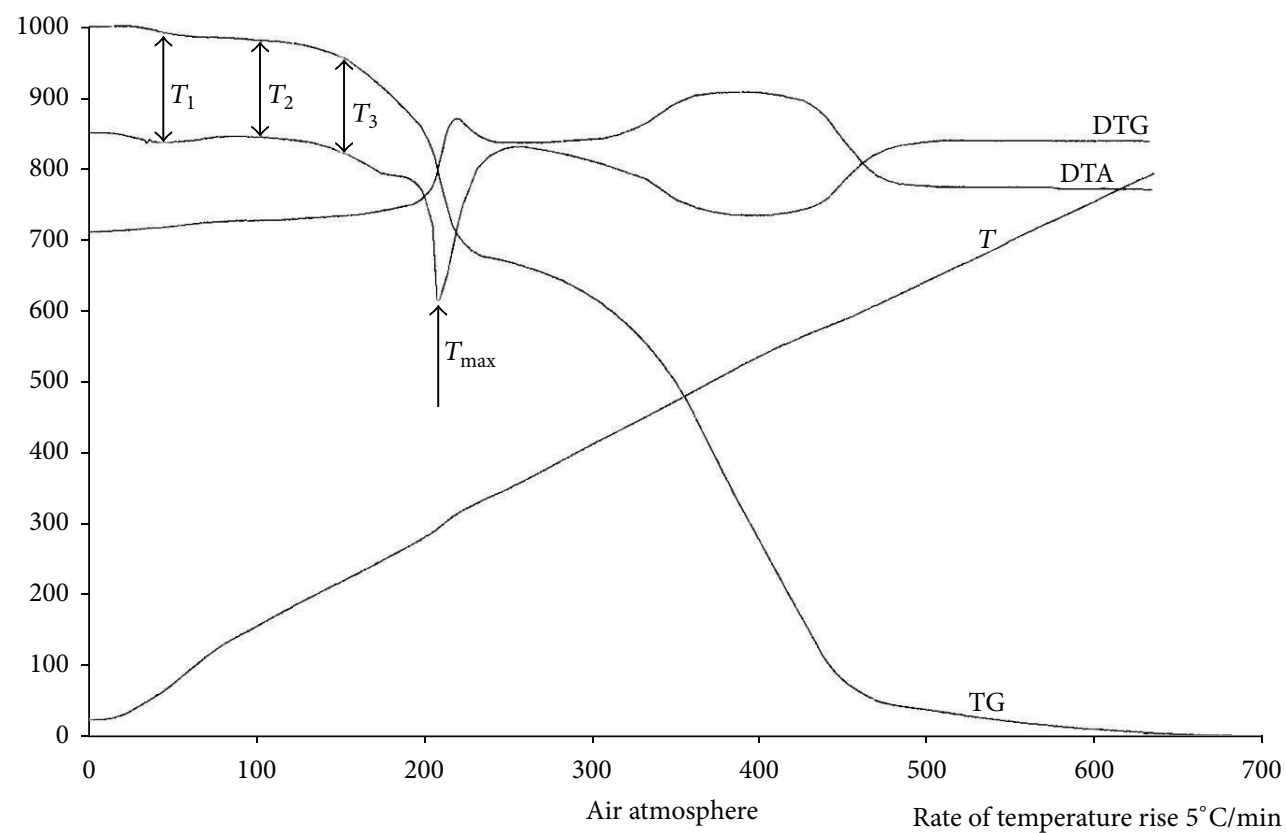

FIgURE 2: Example of thermogram of rigid PUR-PIR foam. Notations of symbols are provided in text.

of recyclate obtained from foam with addition of $15 \% w / w$ of polyethylene glycol were characterized by the lowest brittleness, that is, $18.4 \%$. Softening point of standard foams (without recyclate added, foam 0 ) was $230.0^{\circ} \mathrm{C}$. As the content of recyclates was increased in foam composition from 0.1 to 0.4 of chemical equivalent, softening point decreased from $230^{\circ} \mathrm{C}$ (foam 0 ) to $228.9^{\circ} \mathrm{C}$ (foam 4 ), 226.1 (foam 8), $222.3^{\circ} \mathrm{C}$ (foam 12 ), $218.9^{\circ} \mathrm{C}$ (foam 16 ), $216.4^{\circ} \mathrm{C}$ (foam 20 ), $214.1^{\circ} \mathrm{C}$ (foam
24), 224. $1^{\circ} \mathrm{C}$ (foam 28), 211.9 (foam 32 ), and $209.7^{\circ} \mathrm{C}$ (foam 36 , Table 6), respectively.

Supreme effect on reduction of flammability had the addition of glycolysis products obtained from foams with addition of $15 \% w / w$ of polyethylene glycol 1500 (foams 25 28).

Flammability of these foams decreased what was manifested by increase of oxygen index and retention from $22.1 \%$ 


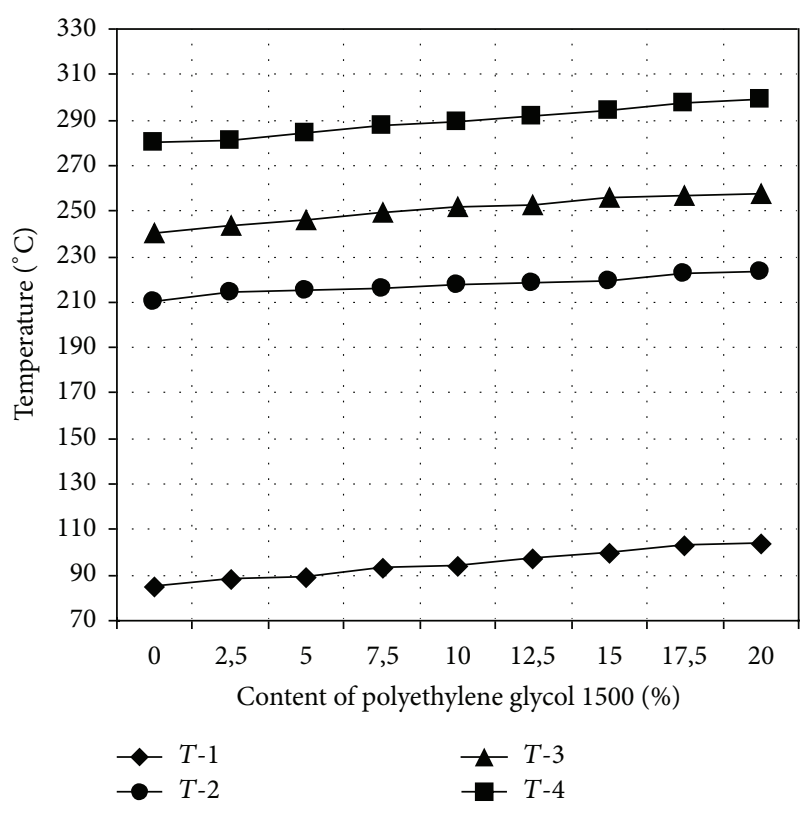

FIGURE 3: Dependence between temperature of decomposition of rigid PUR-PIR foams and content of polyethylene glycol 1500. T1 -temperature of the first loss of foam mass ${ }^{\circ} \mathrm{C}, T-2$ - extrapolated temperature of the beginning of the first loss of foam mass ${ }^{\circ} \mathrm{C}, T-3-$ temperature of the beginning of rapid decomposition ${ }^{\circ} \mathrm{C}$, and $T-4-$ temperature of the highest rate of loss of foam mass ${ }^{\circ} \mathrm{C}$.

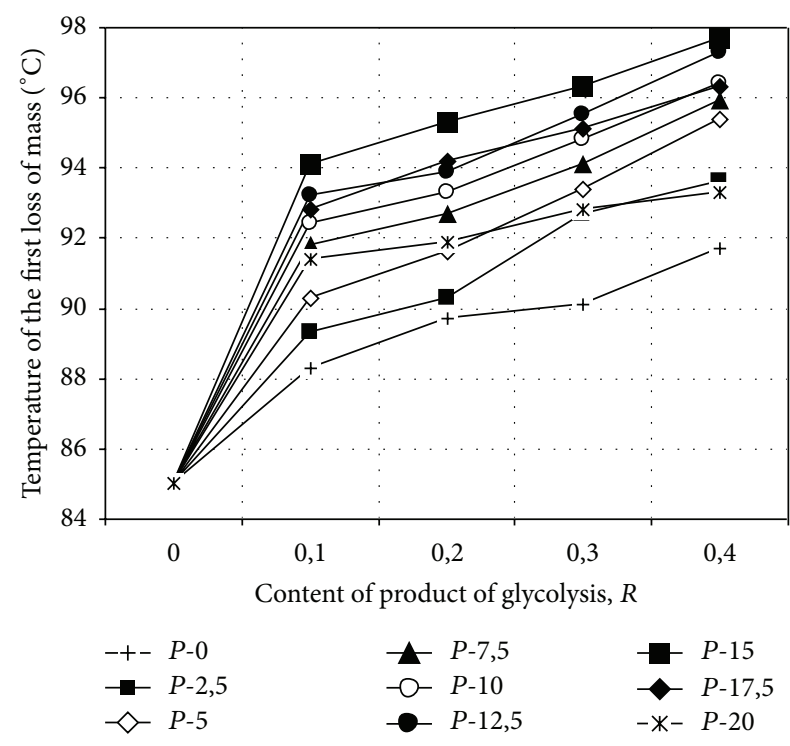

Figure 4: Dependence between the first loss of mass of rigid PURPIR foams and content of product of glycolysis.

and $76.6 \%$ (standard foams, 0 ) to $25.1 \%$ and $86.4 \%$ (foam 28 ), respectively. The lowest effect on flammability has addition of glycolysis products in amounts of $2.5 \% w / w, 5 \% w / w$, and $7.5 \% w / w$.

It was found that addition of recyclates had no effect on percentage change of volume and percentage of mass loss of the new foams.

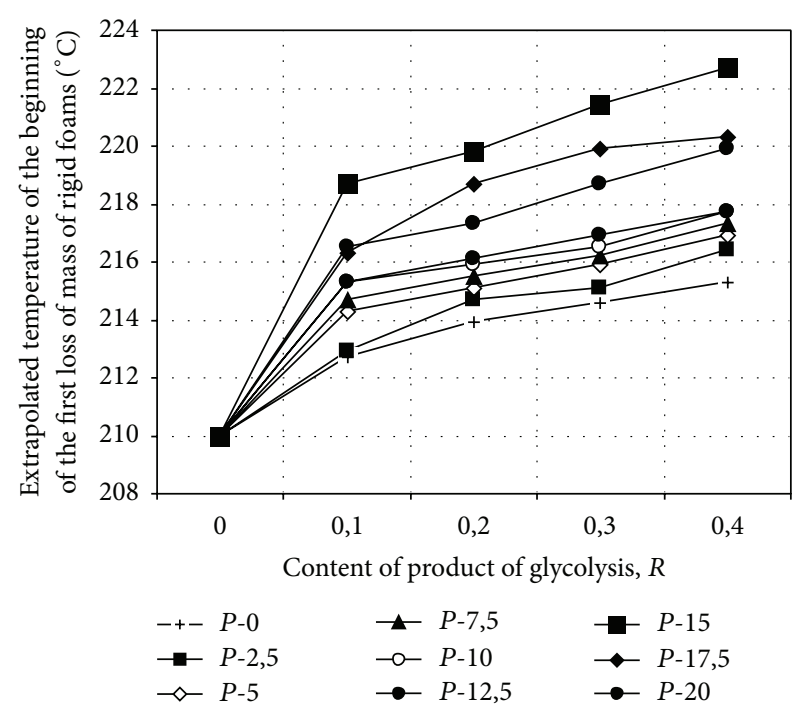

FIGURE 5: Dependence between extrapolated temperature of the beginning of the first loss of mass of rigid PUR-PIR foams and content of product of glycolysis.

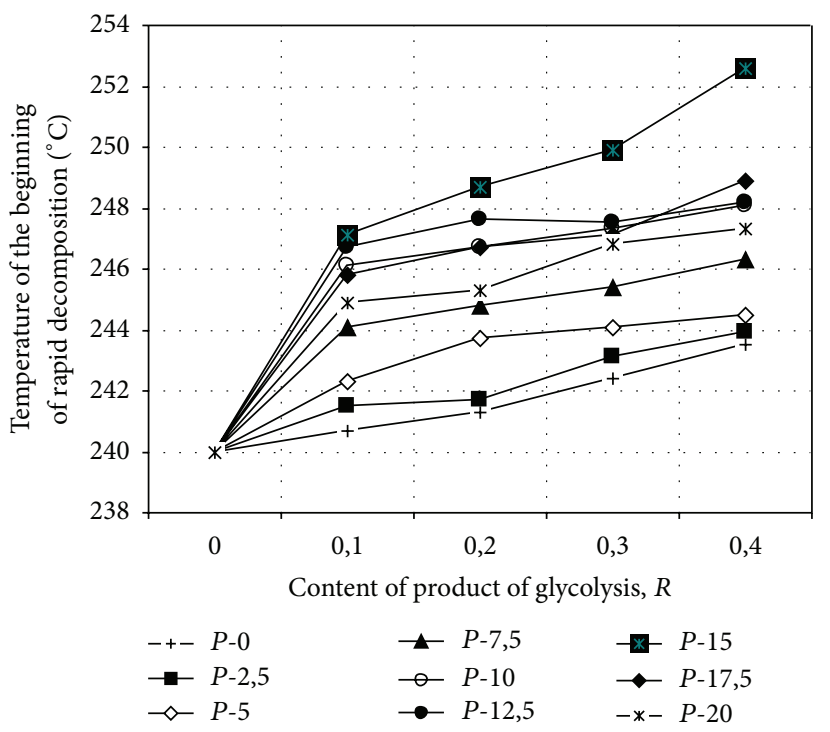

FIGURE 6: Dependence between temperature of the beginning of rapid decomposition of rigid PUR-PIR foams and content of product of glycolysis.

Increasing of the recyclate content in new foams from 0.1 to 0.4 of chemical equivalent resulted in the highest increase of $T_{1}, T_{2}, T_{3}$, and $T_{4}$ in the case of addition of recyclate obtained by glycolysis of foams with addition of $15.0 \% \mathrm{w} / \mathrm{w}$ of polyethylene glycol (foams 25-28 according to Table 5, Figures 3-6). The parameters of foams increased as follows: temperature of the first mass loss from $85^{\circ} \mathrm{C}$ (foam 0 ) to $97.3^{\circ} \mathrm{C}$ (foam 28 , Table 5, Figure 3 ), extrapolated temperature of the beginning of the first mass loss from $210^{\circ} \mathrm{C}$ (foam 0 ) to $222.7^{\circ} \mathrm{C}$ (foam 28 , Figure 4 ), temperature of the beginning of rapid decomposition from $240^{\circ} \mathrm{C}$ (foam 0 ) to $252.6^{\circ} \mathrm{C}$ (foam 


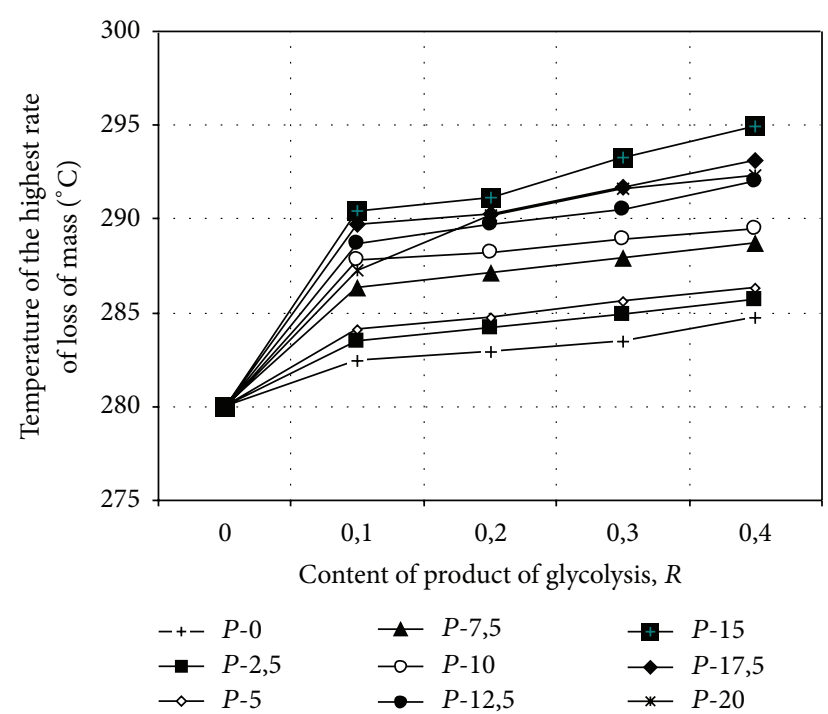

FIGURE 7: Dependence between temperature of the highest rate of loss of mass of the rigid PUR-PIR foams and content of product of glycolysis.

28, Figure 5), and temperature of the highest rate of mass loss from $280^{\circ} \mathrm{C}$ to $294.9^{\circ} \mathrm{C}$ (foam 28, Figure 6).

Addition of recyclates obtained from foam without polyethylene glycol 1500 (foams 1-40, Table 5) has a slight effect on thermal resistance of the new foams (Figures 3-7).

\section{Summary}

Rigid polyurethane-polyisocyanurate foams were prepared by one-stage method at equilibrium ratio of $\mathrm{NCO}: \mathrm{OH}$ groups equal to $3: 1$, with addition of polyethylene glycol. Waste foams were subjected to chemical recycling (glycolysis). The obtained products of glycolysis, after the determination of basic properties (hydroxyl number) required to define the recipe, were applied to prepare the new foams.

It was found that the use of polyethylene glycol had an effect on reduction of brittleness, softening point, and increase of compressive strength. Maximum reduction of foam flammability in comparison to standard foam (the highest retention and oxygen index) was observed in the foams with the highest content of polyethylene glycol. Introducing polyethylene glycol 1500 in amount from $0 \%$ to $20 \% w / w$ into rigid PUR-PIR foams had a slight effect on their thermal resistance determined by the method of thermogravimetric analysis. Polyethylene glycol 1500 fulfills the role of reactive filler in foam.

Glycolysis of waste foams with addition of polyethylene glycol proceeded without disturbances. After 4 hours lasting glycolysis, the liquid products were obtained which, after the determination of hydroxyl number, were applied to prepare the new foams. Addition of the obtained products of glycolysis has an effect on physicomechanical properties of foams. Foams obtained from products of glycolysis with $15 \% w / w$ of polyethylene glycol 1500 were characterized by the best properties in comparison with standard foam (with no recyclate added). As the amount of recyclate was increased in foam composition from 0.0 to 0.4 of chemical equivalent, at simultaneous decrease of Rokpol RF-55 by the same quantity, apparent density, compressive strength, oxygen index, retention, and thermal resistance (thermogravimetric analysis) increased and brittleness decreased. Thus, products of glycolysis can be successfully applied to prepare the new foams. When they are applied as polyol in polyurethane premix, they react with polyisocyanate with formation of macromolecular polyurethane.

\section{Conflict of Interests}

The authors declare that there is no conflict of interests regarding the publication of this paper.

\section{References}

[1] G. Woods, The ICI Polyurethanes Book, John Wiley \& Sons, New York, NY, USA, 1987.

[2] K. Uhlig, Discovering Polyurethanes, Hanser, Munich, Germany, 1999.

[3] E. Placido, M. C. Arduini-Schuster, and J. Kuhn, "Thermal properties predictive model for insulating foams," Infrared Physics \& Technology, vol. 46, no. 3, pp. 219-231, 2005.

[4] B. Czupryński, J. J. Paciorek-Sadowska, and J. Liszkowska, "Properties of rigid polyurethane-polyisocyanurate foams modified with the selected fillers," Journal of Applied Polymer Science, vol. 115, no. 4, pp. 2460-2469, 2010.

[5] D. Randall and S. Lee, Eds., The Polyurethanes Book, John Wiley \& Sons, 2002.

[6] G. Oertel, Polyurethane Handbook, Hanser, Munich, Germany, 2nd edition, 1994.

[7] J. Datta and M. Rohn, "Structure, thermal stability and mechanical properties of polyurethanes based on glycolysate from polyurethane foam waste, prepared with use of 1,6-hexanediol as a glycol," Polimery/Polymers, vol. 53, no. 11-12, pp. 871-875, 2008.

[8] M. Ionescu, Chemistry and Technology of Polyols for Polyurethanes, Rapra Technology, 2005.

[9] J. Scheirs, Polymer Recycling, John Wiley \& Sons, 2001.

[10] J. Datta and K. Pniewska, "Syntheses and properties of polyurethanes got from glycolysis products obtained from waste polyurethane foams," Polimery/Polymers, vol. 53, no. 1, pp. $27-32,2008$

[11] J. Lubczak, B. Łukasiewicz, and B. Myśliwiec, "Synthesis and applications of oligoetherols with perhydro-1,3,5-triazine ring and boron," Journal of Applied Polymer Science, vol. 127, no. 3, pp. 2057-2066, 2013.

[12] K. Kozłowski, H. Masłowski, and B. Czupryński, Pat. PRL, nr 94455, 1978.

[13] H.-R. Lin, "The structure and property relationships of commercial foamed plastics," Polymer Testing, vol. 16, no. 5, pp. 429443, 1997.

[14] A. Prociak, "Cell structure and thermal conductivity of rigid polyurethane foams blown with cyclopentane in different moulds," Polyurethanes Magazine International, vol. 02, p. 102, 2006. 
[15] B. Czupryński and J. Paciorek-Sadowska, "Studies on utylization of rye slops in production of rigid polyurethanepolyisocyanurate foams," Polish Journal of Applied Chemistry, vol. 44, p. 173, 2000.

[16] B. Czupryński, J. Paciorek-Sadowska, and J. Liszkowska, "Studies on effect of Tri(2-hydroxypropyl), Tri(2-hydroxybutyl) and Tri(hydroxythiodiethylene) borates on thermal and heat properties of rigid polyurethane-polyisocyanurate foams," Chinese Journal of Chemistry, vol. 24, no. 12, pp. 1796-1799, 2006.

[17] J. Lubczak, "Polyurethane foams with purine rings," Polimery/Polymers, vol. 52, no. 7-8, pp. 595-600, 2007.

[18] Z. K. Brzozowski, D. Kijeńska, and W. Zatorski, "New achievements in fire-safe polyurethane foams," Designed Monomers \& Polymers, vol. 5, no. 2-3, pp. 183-193, 2002. 

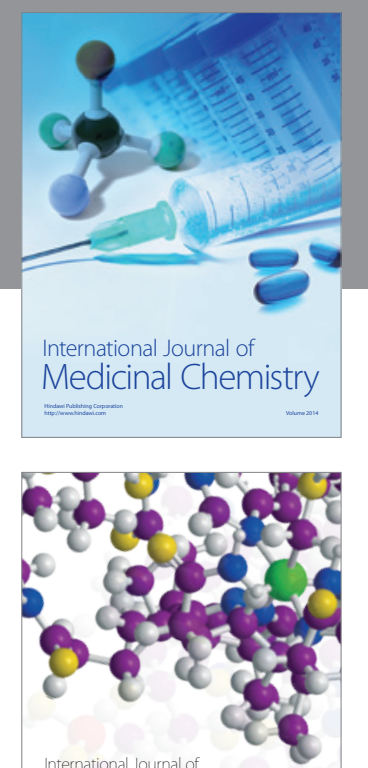

\section{Carbohydrate} Chemistry

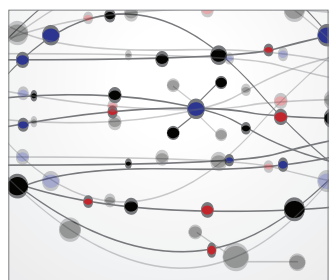

The Scientific World Journal
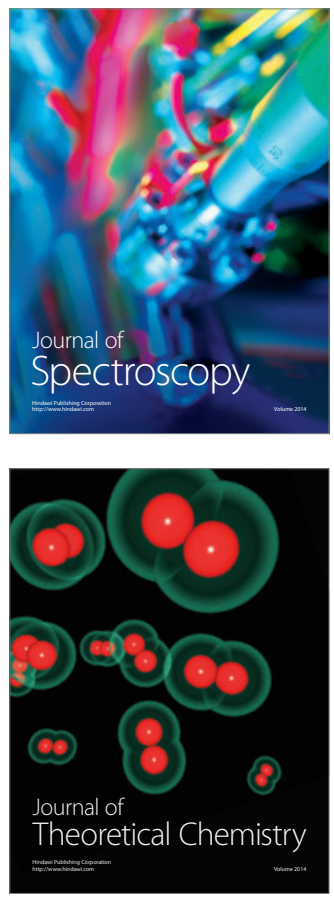
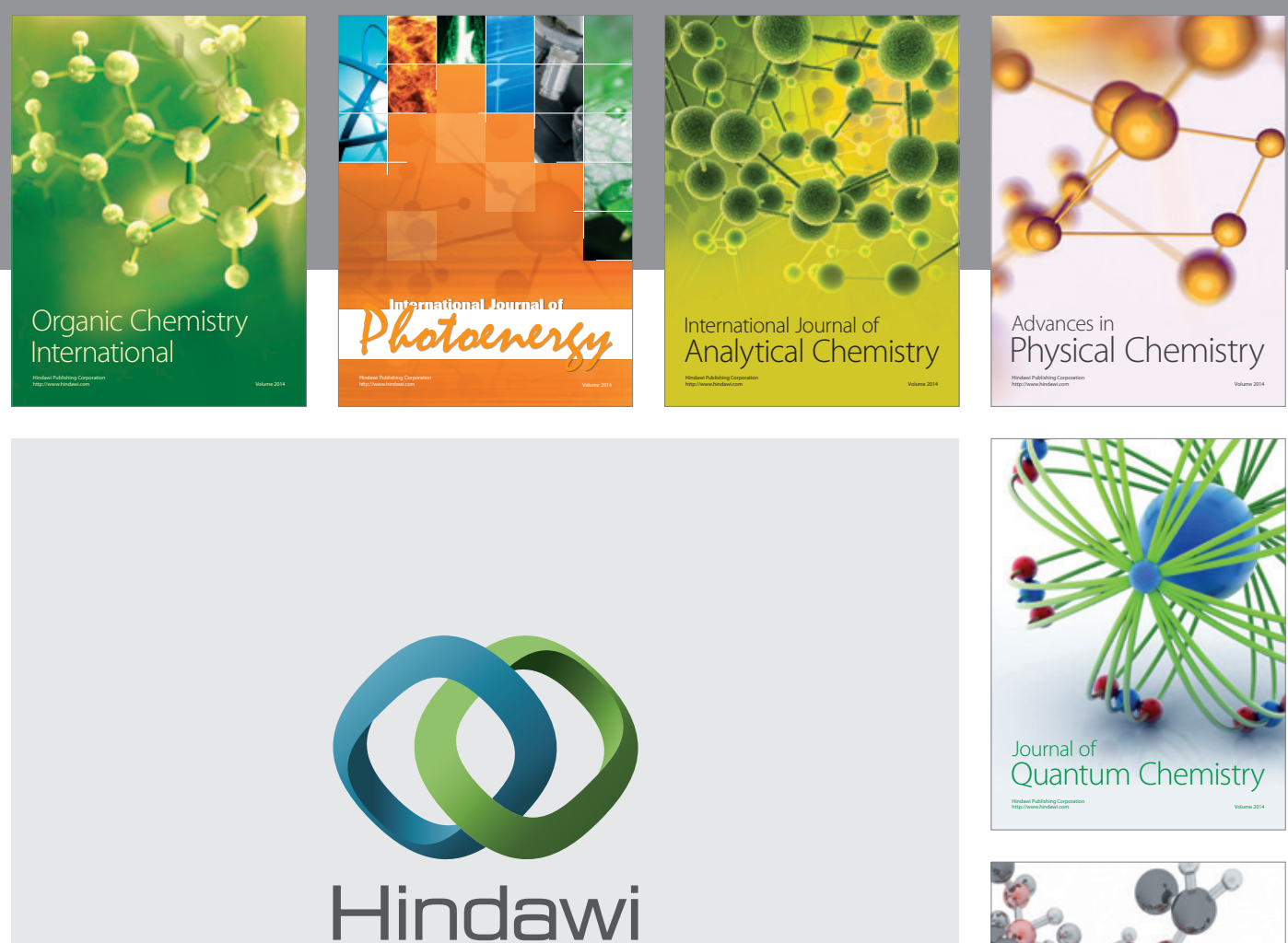

Submit your manuscripts at

http://www.hindawi.com

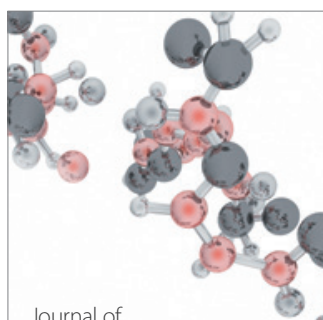

Analytical Methods

in Chemistry

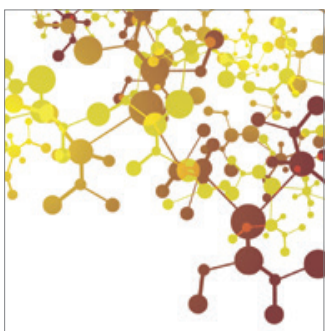

Journal of

Applied Chemistry

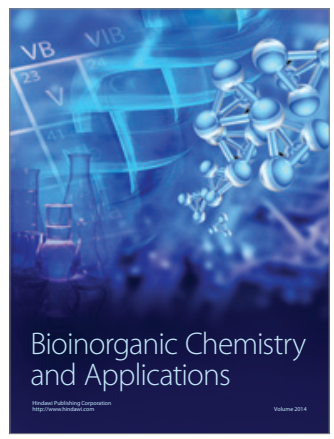

Inorganic Chemistry
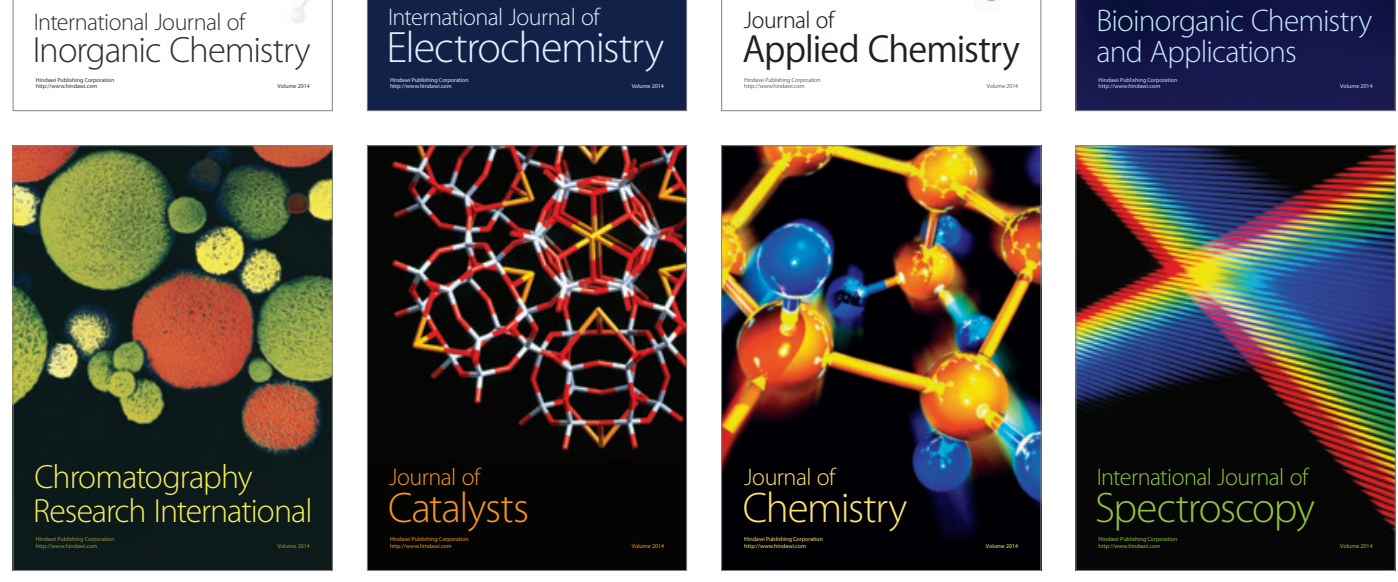